\title{
基 \\ Pregnancy rate after FTAI in Braford heifers submitted to J-Synch protocol
}

[Taxa de prenhez na IATF em novilhas Braford submetidas ao protocolo J-Synch]

\section{"Scientific Article/Artigo Científico"}

\author{
Pablo Sebastián Reineri ${ }^{1,2,3, a}$, Maria Sumampa Coria $^{2,3,4, a}$, Santiago Principi ${ }^{5, a}$, Rodrigo Punta \\ Perez $^{5,6}$, Gustavo Adolfo Palma ${ }^{2,3,4 *}$
}

\author{
${ }^{1}$ National Institute of Agricultural Technology (INTA), EEA Santiago del Estero, La Abrita-Santiago del Estero, \\ G4206XBK, Argentina. \\ ${ }^{2}$ Faculty of Agronomy and Agribusiness (FAyA), National University of Santiago del Estero (UNSE), Santiago del \\ Estero, G4206XCP, Argentina. \\ ${ }^{3}$ Animal Production and Reproduction Laboratory, NOA Institute of Bionanotechnology (INBIONATEC), Villa El \\ Zanjón, Santiago del Estero, G4206XCP, Argentina. \\ ${ }^{4}$ National Council of Scientific and Technical Research (CONICET), Buenos Aires, C1033AAJ, Argentina. \\ ${ }^{5}$ Private activity, Santiago del Estero, Argentina. \\ ${ }^{6}$ Agricultural Technical University Sevilla, University Sevilla (US), Spain. \\ ${ }^{a}$ These authors contributed equally to this work. \\ *Corresponding author/Autor para correspondência: E-mail: gustavo.palma@ reprobiotec.com
}

\begin{abstract}
The objective of the present work was to evaluate the effect of J-Synch protocol on pregnancy rate (PR) of heifers artificially inseminated after detected estrus (DEAI) or at fixed-time (FTAI). Two hundred ninety-three Braford heifers were used. On day 0, all animals received $2.0 \mathrm{mg}$ of estradiol benzoate administered intramuscularly (IM) and an intravaginal progesterone-releasing device (DIB, $0.5 \mathrm{~g}$ ). Heifers were assigned to the following group: 1) J-Synch: on day 6, DIB devices were removed and $500 \mu \mathrm{g}$ of d-Cloprostenol sodium (d-CS) was administered IM and paint was applied on tail base (tail-paint). On day 9 (60 h after DIB removal), heifers with $\geq 40 \%$ of the tail-paint rubbed off were inseminated. Those not showing estrus by $72 \mathrm{~h}$ after DIB removal received $100 \mu \mathrm{g}$ of GnRH at that time and were FTAI. 2) Conventional: on day 7, DIB devices were removed, and $500 \mu \mathrm{g}$ of d-CS and $0.5 \mathrm{mg}$ of estradiol cypionate were administered IM and tail-paint. Fortyeight hours after DIB removal, heifers with the tail-paint rubbed off were DEAI. Those not showing estrus by $54 \mathrm{~h}$ after DIB removal were FTAI. Pregnancy rate was diagnosed by ultrasonography 30 days after FTAI in all heifers and did not differ between protocols $(44.28 \%$ and $42.48 \%, \mathrm{P}=0.673)$. In both protocols, higher PR was observed in DEAI heifers $(\mathrm{P}=0.047)$. In conclusion, the use of the $\mathrm{J}$-Synch protocol generated similar PR to the Conventional protocol, allowing its use with the same efficiency. Furthermore, the DEAI generated better PR than the FTAI, regardless of the protocol used.
\end{abstract}

Keywords: estrus; synchronization protocols; GnRH; tail-paint.

\section{Resumo}

O objetivo do presente trabalho foi avaliar o efeito do protocolo J-Synch na taxa de prenhez (TP) de novilhas artificialmente inseminadas após a ocorrência de estro (DEAI) ou em tempo fixo (FTAI). Duzentas e noventa e três novilhas Braford foram usadas. No dia 0 , todos os animais receberam 2,0 mg de benzoato de estradiol administrado por via intramuscular (IM) e um dispositivo intravaginal de liberação de progesterona (DIB, 0,5 g). As novilhas foram distribuídas nos seguintes grupos: 1) J-Synch: no dia 6, os dispositivos DIB foram removidos e $500 \mu \mathrm{g}$ de d-Cloprostenol sódico (d-CS) foi administrado IM e a tinta foi aplicada na base da cauda (tinta da cauda). No dia 9 (60 h após a remoção do DIB), as novilhas com a tinta removida ( $\geq 40 \%)$ foram inseminadas. Aquelas que não apresentaram estro em 72 horas após a remoção do DIB receberam 100 $\mu \mathrm{g}$ GnRH no momento da IATF. 2) Convencional: no dia 7, os dispositivos DIB foram removidos e $500 \mu \mathrm{g}$ de d-CS e 0,5 mg de cipionato de estradiol foram administrados IM e tinta da cauda. Quarenta e oito horas após a remoção do DIB, as novilhas com a tinta removida foram DEAI. Aqueles que não apresentaram estro 
54 h após a remoção do DIB foram FTAI. A prenhez foi diagnosticada por ultrassonografia 30 dias após a FTAI em todas as novilhas. A TP não diferiu entre os protocolos $(44,28 \%$ e 42,48\%, $\mathrm{P}=0,673)$. Porém, em ambos os protocolos, maior TP foi observada em novilhas DEAI $(\mathrm{P}=0,047)$. Concluindo a utilização do protocolo J-Synch gerou TP semelhantes ao protocolo convencional, permitindo sua utilização com a mesma eficácia. Além disso, a DEAI gerou melhores TP do que a FTAI, independentemente do protocolo utilizado.

Palavras-chave: estro; protocolos de sincronização; GnRH; tinta da cauda.

\section{Introduction}

Estrous cycle synchronization protocols have been used worldwide to increase reproductive efficiency of beef cattle. The control of the estrous cycle based on the use of intravaginal devices with progesterone allows to synchronize the ovulation in cyclical animals and induces ovarian activity in those that are in anestrus (Delgado et al., 2016). In recent years, progress has been made in the development of fixed-time artificial insemination (FTAI) protocols based on the use of different estradiol salts and progesterone for estrous synchronization in bovine cattle (Bó et al., 2018). For this purpose, several FTAI protocols have been commercially adopted in reproductive management programs. In South America and Australia, the most common is an estradiol-based protocol (Bó et al., 2016) that usually starts with the intravaginal insertion of a progesterone-device and the intramuscular (IM) injection of estrogen salts, typically estradiol benzoate (EB). The progesterone protocol length varies between seven to eight days and the goal is to induce atresia of existing follicles and stimulates a new follicular wave three to four days after device insertion. At device withdraw, a luteolytic dose of prostaglandin $\mathrm{F} 2 \alpha\left(\mathrm{PGF}_{2 \alpha}\right)$ is injected, followed by administration of estradiol salt between 46 to 56 hours, to induce ovulation (Bó et al., 2018).

A new protocol for FTAI, named J-Synch, was developed to prolong the interval between progesterone-device removal to ovulation, increasing the period of estradiol exposure and improving uterine function (de la Mata and Bó, 2012). The protocol consists on administration of EB concurrently with the intravaginal insertion of a progesterone-device, which is removed six days later. A single dose of $\mathrm{PGF}_{2 \alpha}$ is given at device withdraw and animals receive $\mathrm{GnRH}$ at the time of FTAI, 72 hours later (Bó et al., 2018). The results obtained with this protocol have shown higher pregnancy rates compared to conventional protocol in Hereford, Angus, Simmental and Simangus cows and heifers (Menchaca et al., 2014; de la Mata et al., 2015; 2018; Bó et al., 2018). However, some studies reported no difference between conventional and J-Synch protocol in Bos taurus heifers (de la Mata and Bó, 2012; Dominicis et al., 2019). Moreover, studies published in Bos indicus heifers and cows suggest that there is no positive effect of J-Synch protocol in pregnancy rate (Motta et al., 2016; Bonotto et al., 2017; Mion et al., 2019). Therefore, the aim of this study was to evaluate the effect of J-Synch protocol on pregnancy rate in Braford heifers artificially inseminated after estrus detection (DEAI) or at fixed time, compared to conventional protocol.

\section{Materials and Methods}

\section{Location and animals}

This study was carried out in "Frontera del Salado" establishment, located in Malbrán, Argentina (S29 $\left.{ }^{\circ} 15^{\prime} 49.34^{\prime \prime}-\mathrm{W} 62^{\circ} 11^{\prime} 05.16^{\prime \prime}\right)$. All the procedures were performed according to the rules and regulations of the Institutional Committee for Care and Use of Experimental Animals of the National Institute of Agricultural Technology (CICUAE-INTA). Two hundred ninety-three Braford heifers, with 22-24 months of age and weighing $320 \pm 2 \mathrm{~kg}$ (mean \pm standard error of the mean [SEM]) with a body condition score (BCS) mean of $2.9 \pm 0.25$ (mean \pm SEM), 1 to 5 scale (Richards et al., 1986) and weighting more than $300 \mathrm{~kg}$ were used. Reproductive tract abnormalities and cyclicity (pubertal status, by presence of the corpus luteum and/or follicles $\geq 10$ millimeters in diameter) were determined 30 days before beginning the study, performing two ultrasonographic evaluations 11 days apart. Heifers with reproductive disorders were excluded from the study. A completely randomized design with two repetitions was used, and animals were assigned into two groups: Conventional and JSynch protocols.

\section{Experimental protocols}

On day 0 , all heifers received $2.0 \mathrm{mg}$ of EB (Gonadyol, Syntex, Argentina) administered IM and an intravaginal releasing device containing 0.5 $\mathrm{g}$ of progesterone (DIB) (DIB 0.5, Syntex, Argentina). Heifers were randomly assigned to the following group: 1) J-Synch $(n=140)$ : on day 6, DIB was removed, $500 \mu \mathrm{g}$ d-Cloprostenol sodium 
(d-CS) (Ciclase DL, Syntex, Argentina) was administered IM, and paint was applied on tail base (tail-paint) (Celo-test, Biotay S.A) to detect heifers in estrous. On day 9, (60 hours after DIB removal), heifers with the tail-paint rubbed off $(\geq 40 \%)$ were DEAI. Those not showing estrus by $72 \mathrm{~h}$ after, received $100 \mu \mathrm{g}$ of GnRH (Gestran Plus, Arsa SRL, Argentina) at that time and were FTAI. 2) conventional $(n=153)$ : on day 7 , DIB was removed, $500 \mu \mathrm{g}$ of $\mathrm{d}-\mathrm{CS}$ and $0.5 \mathrm{mg}$ of ECP (Cipiosyn ${ }^{\circledR}, \quad$ Syntex SA, Argentina) were administered IM, and tail-painted. Forty-eight hours after DIB withdrawal, heifers with tail-paint rubbed of $\geq 40 \%$ were DEAI and those not showing estrous were FTAI 54 hours after DIB removal (Figure 1). The AI was performed by only one technician with frozen-thawed semen from one bull available commercially with proven fertility. Fourteen days after FTAI, heifers were exposure to bulls for 30 days (proportion of bulls to cows of $1: 20)$.

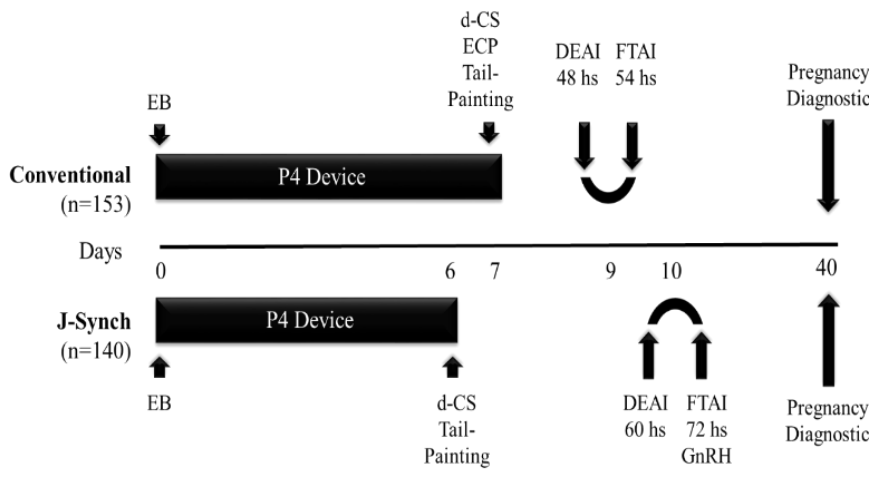

Figure 1. Protocols made during the experimental period. EB: estradiol benzoate, P4 Device: intravaginal progesterone-releasing device containing $0.5 \mathrm{~g}$ of progesterone, d-CS: $\mathrm{d}-$ Cloprostenol sodium, DEAI: artificial insemination after detected estrus, FTAI: fixed-time artificial insemination, GnRH: Gonadotropin-releasing hormone.

\section{Pregnancy diagnosis}

Heifers were evaluated for pregnancy by ultrasonography 30 days after FTAI (Mindray Z5Vet, Shenzhen, China), using the ultrasound with a 7.5 MHz linear transducer, (Chison Medical Imaging Co., Ltd., Wuxi, China). Positive diagnosis of pregnancy was determined as the presence of an embryo or fetus with heartbeat, visible fetal movements, and the presence of clear amniotic fluid (Kastelic et al., 1988; Reineri et al., 2018).

\section{Statistical analysis}

Pregnancy rate were analyzed as a completely randomized design, with two repetitions (BCS in Repetition 1: J-Synch [n: 70] $2.85 \pm 0.03$ vs. Conventional [n: 73] $2.90 \pm 0.03$ and in Repetition 2: Conventional [n: 80] $2.86 \pm$ 0.02 vs. J-Synch [n: 70] $2.91 \pm 0.02$ ). InfoStat software was used (Di Rienzo et al., 2017). Multiple logistic regression was adjusted to determine the effect of different factors on the pregnancy rates in each protocol. Regression coefficients and odds ratios were obtained as the output of this model. In all statistical analyzes, the level of significance was set at $\mathrm{P}=0.05$. The trend was considered when the $P$ value was between 0.10 and 0.05 .

\section{Results}

No significant differences between repetitions were observed within the same protocol (P> 0.05). Therefore, the effect of protocols on pregnancy rate was evaluated. Table 1 shown pregnancy rate of the heifers in the J-Synch and Conventional protocols. The pregnancy rate obtained was $44.3 \%$ in heifers that received the $\mathrm{J}$ Synch protocol, and $42.5 \%$ in heifers that received the conventional protocol $(\mathrm{P}=0.673)$. On the other hand, estrus expression was detected in $30.4 \%$ $(89 / 293)$ of synchronized heifers. No significant differences were observed in the number of heifers displaying estrus between the J-Synch protocol $(32 \%)$ vs. conventional protocol $(28 \%)(\mathrm{P}=0.520)$. However, pregnancy rates were higher in heifers DEAI independently of the protocol used $(\mathrm{P}=$ 0.047).

Table 1. Pregnancy per artificial insemination according to estrus detection of beef heifers treated with Conventional or J-Synch protocol.

\begin{tabular}{cccc}
\hline \multirow{2}{*}{ Group } & \multicolumn{3}{c}{ Pregnancy per artificial insemination } \\
\cline { 2 - 4 } & DEAI & FTAI & Overall \\
\hline Conventional & $57,1 \%(28 / 49)^{\mathrm{b}}$ & $35,7 \%(34 / 104)^{\mathrm{a}}$ & $42,5 \%(65 / 153)$ \\
J-Synch & $55,0 \%(22 / 40)^{\mathrm{b}}$ & $40,0 \%(40 / 100)^{\mathrm{a}}$ & $44,3 \%(62 / 140)$ \\
\hline
\end{tabular}

DEAI: artificial insemination at detected estrus, FTAI: fixed-time artificial insemination

${ }^{a, b}$ Different letters in the same line indicate statistical difference between heifers that displayed estrus or not in the same protocol $(\mathrm{p}<0,05)$. 


\section{Discussion}

The results showed that pregnancy rates were similar between J-Synch protocols and conventional. However, it was described that the length of the proestrus can affect the results of FTAI (Bridges et al., 2010). In this sense, short proestrus reduces follicular growth, leading to low serum estradiol concentrations, smaller ovulatory follicle and corpus luteum diameters, and consequently lower fertility (Bridges et al., 2010; Dadarwal et al., 2013). These findings led to the implementation of protocols such as J-Synch, to prolong the length of the proestrus.

A previous study indicate that $\mathrm{J}-\mathrm{Synch}$ protocol produces late ovulation (28 hours apart), increases dominant follicle growth rate, with higher concentration of progesterone between days 6 and 12 post ovulation and a mature uterine environment (lower proportion of progesterone receptors) (de la Mata et al., 2018). Therefore, an improvement in the fertility was obtained in artificially inseminated females after generating prolonged proestrus (de la Mata et al., 2015; Menchaca et al., 2014; Macmillan et al., 2020; Núñez-Olivera et al., 2020). Recent studies carried out with Angus, Simmental, Simangus, and Hereford heifers (Bó et al., 2018; de la Mata et al., 2015; 2018) and on heifers and cross Angus and Simmental cows (McMillan et al., 2020) with body condition score higher than 3 (scale 1 to 5), obtained higher pregnancy rates after J-Synch protocol than Conventional. In contrast to the present study, it should be noted that equine chorionic gonadotropin (eCG) was administered at DIB device withdrawal in the reported studies. Previous research suggest that, the administration of eCG stimulates the growth of the dominant follicle and therefore the pregnancy rate (Bó et al., 2016, 2018). Moreover, some authors described pregnancy rate was enhanced by eCG treatment and the improvement was more evident when FTAI/GnRH was performed at 72 hours after device removal (de la Mata et al., 2018; NúñezOlivera et al., 2020).

Similar to the results obtained in the present work, no differences were reported between JSynch and conventional protocols in studies carried out with Bos taurus heifers between 13 to 17 months of age without eCG administration at DIB withdrawal (de la Mata and Bó, 2012; Dominicis et al., 2019). Likewise, the implementation of the JSynch protocol did not produce differences compared with conventional protocol in Bos indicus (Edwards et al., 2015; Motta et al., 2016;
Bonotto et al., 2017; Cedeño et al., 2019; Mion et al., 2019). Furthermore, the studies carried out on Braford heifers with 22 months of age and body conditions between 3 and 3.5, did not show significant differences between the J-Synch and conventional protocols (Bonotto et al., 2017; Mion et al., 2019). In this sense, differences obtained between the different studies could be due to the number of animals used by protocols, breeds, ages, and body condition scores of the animals evaluated. Differences were observed only in studies performed with Bos taurus heifers between 13 to 17 months of age with BCS higher than 2.5 (scale 1-5) with eCG administration. J-Synch protocol not produces differences in Bos taurus heifers with similar age and better BCS ( $>3$, scale 1-5), without eCG administration. Furthermore, J-Synch protocol generates similar pregnancy rates than Conventional in 22-24 months aged Bos indicus heifers with higher BCS ( $\geq 3$, scale 1-5) with or without eCG administration.

Estrus detection was performed in $30.4 \%$ of all synchronized heifers (89/293), similar to a previous study performed in Braford heifers, and higher than in cows (Mion et al., 2019). The proportion of heifer with estrus expression obtained could occur due to follicular wave shortening, with females demonstrating estrus closer to the moment of decreased progesterone concentration (Rivera et al., 2005). The effect of DEAI and FTAI was also evaluated and higher pregnancy rate was higher in animals whose estrous was detected (tail-paint rubbed off). Similar to the current results, it was reported that AI after estrus detection, was associated with higher fertility (de la Mata and Bó, 2012; Bonotto et al., 2017; Macmillan et al., 2020; Mion et al., 2019). Sá Filho et al. (2011) reported cows that displayed estrus following an estradiol and progesterone based synchronization protocol, have a larger follicular diameter, increased ovulation rate, and larger corpus luteum, resulting in a higher concentration of progesterone after AI, favoring the pregnancy rate.

In conclusion, under these study conditions, the use of the J-Synch protocol generated similar PR to the Conventional protocol, allowing its use with the same efficiency. Furthermore, the DEAI generated better PR than the FTAI, regardless of the protocol used. Therefore, the combination of DEAI and FTAI could be beneficial to improve pregnancy rates. 


\section{Conflict of interest}

We certify that there is no conflict of interest with any financial organization regarding the material discussed in the manuscript.

\section{Ethics Committee}

The Institutional Committee for the Care and Use of Experimental Animals (CICUAE) of the National Institute of Agricultural Technology (INTA) approved all procedures performed in this experiment (Protocol ID CICUAE 05-2019).

\section{Acknowledgments}

Original research was supported by the National Institute of Agricultural Technology [PDE5-I107-001], National University of Santiago del Estero [23/A262], National Council for Scientific and Technological Research (CONICET) [PUE 2018 0035] and PIMA scholarships. The authors would like to acknowledge Ditges Family who provided their facilities, animals, semen, and hormones for the experiment and Dr. Parellada for technical work in the laboratory.

\section{References}

Bó, G.A.; de la Mata, J.J.; Baruselli, P.S.; Menchaca, A. Alternative programs for synchronizing and resynchronizing ovulation in beef cattle. Theriogenology, 86: 388-396, 2016.

Bó, G.A.; Huguenine, E.; de la Mata, J.J.; NúñezOlivera, R.; Baruselli, P.S.; Menchaca, A. Programs for fixed-time artificial insemination in South American beef cattle. Animal Reproduction, 15: 952-962, 2018.

Bonotto, A.L.M.; Mion, B.; Bonotto, R.M.; Farias, C.O.; Rosa, F.S.; Schneider, A. Evaluation of the J-Synch protocol associated with eCG and estrous detection in beef heifers. Animal Reproduction, 14(3): 670, 2017.

Bridges, G.A.; Mussard, M.L.; Burke, C.R.; Day, M.L. Influence of the length of proestrus on fertility and endocrine function in female cattle. Animal Reproduction Science, 117: 208-215, 2010.

Cedeño, A.; Maingón, R.; Cedeño, J.; Guadalupe, C.; Morales, L.; Pinargote, L.; Figueroa, V.; Bó, G. Follicular and luteal characteristics and pregnancy rates in Bos indicus suckled cows treated with two oestradiol/progesterone-based protocols with a prolonged pro-oestrus. Reproduction, Fertility and Development, 32: 212-213, 2019.

Dadarwal, D.; Mapletoft, R.J.; Adams, G.P.;
Pfeifer, L.F.M.; Creelman, C.; Singh, J. Effect of progesterone concentration and duration of proestrus on fertility in beef cattle after fixedtime artificial insemination. Theriogenology, 79: 859-866, 2013.

de la Mata, J.J.; Bó, G.A. Estrus synchronization and ovulation using protocols with estradiol benzoate and GnRH and reduced periods of insertion of a progesterone releasing device in beef heifers. Taurus, 55: 17-23, 2012.

de la Mata, J.J.; Ré, M.; Bó, G.A. Combination of oestrus detection and fixed-time artificial insemination in beef heifers following a shortened oestradiol-based protocol that provides for a lengthened proestrus. Reproduction, Fertility and Development, 27: 96-97, 2015.

de la Mata, J.J.; Núñez-Olivera, R.; Cuadro, F.; Bosolasco, D.; De Brun, V.; Meikle, A.; Bó, G.A.; Menchaca, A. Effects of extending the length of pro-oestrus in an oestradiol- and progesterone-based oestrus synchronisation program on ovarian function, uterine environment and pregnancy establishment in beef heifers. Reproduction, Fertility and Development, 30: 1541-1552, 2018.

Delgado, P.A.M.; Cuéllar, N.R.; Sánchez, C.M.G.; Rojas, E.C.C. Dinamica folicular en la vida reproductiva de la hembra bovina. Veterinária e Zootecnia, 5: 88-89, 2016.

Di Rienzo, J.A.; Casanoves, F.; Balzarini, M.G.; Gonzalez, L.; Tablada, M.; Robledo, C.W. InfoStat versión 2017. Argentina: Grupo InfoStat, FCA, Universidad Nacional de Córdoba. Available at: <URL http://www.infostat.com.ar>. Accessed on: 26 August 2020.

Dominicis, O.; Madero, S.; Catalano, R.; Cabodevila, J.; Callejas, S. Efecto del tratamiento J-Synch sobre el porcentaje de preñez en vaquillonas para cría inseminadas a tiempo fijo. Revista Veterinaria, 30(2): 31-35, 2019.

Edwards, S.A.A.; Boe-Hansen, G.B.; Satake, N.; Chandra, K.; McGowan, M.R. A field investigation of a modified intravaginal progesterone releasing device and oestradiol benzoate based ovulation synchronisation protocol designed for fixed-time artificial insemination of Brahman heifers. Animal Reproduction Science, 160: 105-111, 2015.

Kastelic, J.P.; Curran, S.; Pierson, R.A.; Ginther, O.J. Ultrasonic evaluation of the bovine conceptus. Theriogenology, 29: 39-54, 1988. 
Motta, J.C.; Colli, M.H.A.; Penteado, L.; Bayeux, B.M.; Mingoti, R.; Bo, G.; Lugo, L.; Rezende, R.G.; Baruselli, P.S. Pregnancy rate to FTAI in Nelore and crossbreed heifers submitted to JSynch protocol (6 days). Animal Reproduction, 13 (3): 401, 2016.

Macmillan, K.; Gobikrushanth, M.; Sanz, A.; Bignell, D.; Boender, G.; Macrae, L.; Mapletoft, R.J.; Colazo, M.G. Comparison of the effects of two shortened timed-AI protocols on pregnancy per AI in beef cattle. Theriogenology, 142: 85-91, 2020.

Menchaca, A.; Nuñez-Olivera, R.; Cuadro, F.; Bo, G. Pregnancy rates in beef heifers synchronized with a shortened oestradiol-based treatment that provides for a prolonged proestrus. Reproduction, Fertility and Development, 27(1): 96, 2014.

Mion, B.; Bonotto, R.M.; Farias, C.O.; Rosa, F.S.; Pradiee, J.; Rovani, M.T.; Pegoraro, L.M.C.; Bonotto, A.L.M.; Pfeifer, L.F.M.; Schneider, A. J-Synch protocol associated with estrus detection in beef heifers and non-lactating cows. Medicina Veterinária, 13: 269-274, 2019.

Núñez-Olivera, R.; Cuadro, F.; Bosolasco, D.; de Brun, V.; de la Mata, J.; Brochado, C., Meikle, A.; Bó, G.A.; Menchaca, A. Effect of equine chorionic gonadotropin (eCG) administration and proestrus length on ovarian response, uterine functionality and pregnancy rate in beef heifers inseminated at a fixed-time. Theriogenology, 151: 16-27, 2020.

Reineri, P.S.; Piccardi, M.; Arroquy, J.; Fumagalli, A.; Coria, M.S.; Hernández, O.; Bó, G.; Palma, G.A. Hormones and monensin use to improve pregnancy rates in beef cows. Animal Reproduction, 15(1): 56-63, 2018.

Richards, M.W.; Spitzer, J.C.; Warner, M.B. Effect of varying levels of postpartum nutrition and body condition at calving on subsequent reproductive performance in beef cattle. Journal of Animal Science, 62(2): 300-306, 1986.

Rivera, H.; Lopes, H.; Fricke, P.M. Use of intravaginal progesterone-releasing inserts in a synchronization protocol before timed $\mathrm{AI}$ and for synchronization return to estrus in holstein heifers. Journal of Dairy Science, 88: 957-968, 2005.

Sá Filho, M.F.; Santos, J.E.; Ferreira, R.M.; Sales, J.N.; Baruselli, P.S. Importance of estrus on pregnancy per insemination in suckled Bos indicus cows submitted to estradiol/progesterone-based timed insemination protocols. Theriogenology, 76: 455-463, 2011. 